\title{
PLANNED GENTRIFICATION IN ISTANBUL: THE SULUKULE RENEWAL AREA 2005-2010
}

\author{
A. $\mathrm{KOCABAS}^{1} \&$ M.S. GIBSON ${ }^{2}$ \\ ${ }^{1}$ Department of City and Regional Planning, Mimar Sinan Fine Arts University, Istanbul, Turkey. \\ ${ }^{2}$ Emeritus Professor of Urban Planning, London South Bank University and \\ Associate Director JVM Ltd. London, UK.
}

\begin{abstract}
This paper evaluates the first local government-led neighborhood regeneration project in central Istanbul with reference to its neighborhood impact and its wider implications for the future of regeneration in the city. From a perspective rooted in historical and international comparative planning studies, the research methodology is elaborated through an analysis of the evolution of a generic model of contemporary sustainable urban regeneration that provides the analytical framework for the evaluation. A review of the emergence of regeneration in Istanbul since the early 2000s establishes the context and rationale for the Sulukule case study. The paper then presents an analysis of events which led to the total demolition of the historic Sulukule neighborhood and the destruction of its Roma community. These events flowed from the authoritarian implementation of the Sulukule Renewal Area Plan, despite the efforts of civil society organizations to secure the development and implementation of a community-based alternative plan.

The neighborhood level evaluation explains why the redevelopment of Sulukule should be understood as planned gentrification. Evaluation on a wider front is necessary because Sulukule has become the cause celebre in a vigorous debate about the purpose, scope, and outcomes of regeneration, which centers on the question 'whose Historic Peninsula?'. Many argue that regeneration should be stopped, as it inevitably means planned gentrification. But others, including the authors, draw on international experience to argue for the development of an Istanbul/Turkish version of sustainable, conservation-led, and community-based neighborhood regeneration. More widely still, the Sulukule experience has fuelled growing opposition to regeneration per se, epitomized in the slogan 'no Sulukule here'. Thus the paper concludes by outlining the action needed to move toward sustainable regeneration, not only for the city's central historic neighborhoods, but also for the far more numerous poor and deteriorating $20^{\text {th }}$ century neighborhoods where the threat is not from gentrification, but from the next earthquake.

Keywords: evaluation and earthquake threat, gentrification, Istanbul, renewal area, Sulukule, urban and neighborhood regeneration, urban conservation.
\end{abstract}

\section{INTRODUCTION}

In 2005, the Fatih District Municipality proposed the designation of the Neslisah Sultan and Hatice Sultan neighborhoods as a Renewal Area, under the terms of the newly approved urban conservation legislation. This is the first local government-led neighborhood regeneration project in central Istanbul. The Renewal Area is within and adjacent to the western section of Theodosian City Walls, which is part of the Istanbul World Heritage Site, currently under threat of being transferred to the List of World Heritage in Danger, because of inadequate conservation action. The Renewal Area Plan is the basis of the comprehensive redevelopment of the neighborhood, which was the home of the historic Sulukule Romany community. There was no formal consultation with the residents prior to the designation of the Renewal Area being approved by the Greater Istanbul Metropolitan Municipality (GIMM) and the central government's Council of Ministers. Residents learnt of the Mayor's intention to demolish their neighborhood through the press. In July 2006, the Fatih Municipality signed a Protocol with the GIMM and TOKI (the government's mass housing construction agency) for the demolition and comprehensive redevelopment of the Sulukule neighborhood. This marked the beginning of an innovative neighborhood regeneration process, which has resulted in the near total demolition of the neighborhood and the destruction of the local, mainly Roma, community. In 2007, 
a parallel, community-planning process was initiated by the residents' association and NGOs. But this process did not get beyond an embryonic stage and was not able to develop and secure the implementation of a rehabilitation-based alternative plan. Rebuilding began in summer 2010, but it is likely that very few of the original residents will return to their neighborhood - certainly none of the former tenants. The Sulukule regeneration experience was a disaster for the local community. However, if lessons are learnt and acted on, history may record that it was an important milestone on the route toward an Istanbul version of sustainable urban and neighborhood regeneration.

\section{SUSTAINABLE URBAN AND NEIGHBORHOOD RENEWAL: AN EVOLVING INTERNATIONAL CONSENSUS AND A GOAL FOR ISTANBUL}

Our analytical approach to urban and neighborhood regeneration is rooted in historical and international comparative planning studies perspectives. From these perspectives, the research methodology is elaborated through an analysis of the evolution of a generic model of contemporary sustainable urban regeneration. This model provides the analytical framework for the evaluation of the Sulukule experience in its Istanbul context.

The evolving contemporary concept of sustainable regeneration integrates social, economic, and environmental components of urban and neighborhood regeneration. This analysis argues that this concept, and the practice which it underpins, embodies lessons from the experience of four successive, previous (but partially overlapping) generic models of urban and neighborhood regeneration. The first model was comprehensive clearance and redevelopment, which was succeeded by neighborhood rehabilitation and community development. A period dominated by property-led regeneration was followed by a transitional period of integrated area regeneration, which paved the way for the contemporary model of sustainable urban and neighborhood regeneration, which is informing regeneration practices across the EU.

The following analysis elaborates this evolutionary process by reference to UK experience, but there is an evolving international consensus in favor of developing the capacity to deliver sustainable regeneration as a major component of a $21^{\text {st }}$ century transition to sustainable urban development. The application of these models, adapted to different national conditions, is identifiable in many EU countries [1-3]. The analysis concludes that policy makers in Istanbul and Turkey have begun to face up to the challenge of charting Istanbul's route to sustainable urban regeneration and that the impact of the Sulukule experience should be evaluated in this context. Thus our approach is to draw on international experience to evaluate the impact of the regeneration process at two levels. The first level is an assessment of the impact on the historic neighborhood itself, with reference to both the place and to the people who were living there when the regeneration process began. However, the Sulukule Renewal Area is the first neighborhood regeneration project to be implemented in central Istanbul, but it has been widely, indeed internationally, condemned in terms of its negative social and cultural heritage impact. Thus, the second level is evaluation of the wider impact on the future regeneration of the Historic Peninsula and on the many other poor quality, deteriorating, and earthquake vulnerable neighborhoods elsewhere in Istanbul. Our approach is informed by internationally accepted methods which define evaluation as:

'... an assessment, as systematic and objective as possible, of an ongoing or completed project, programme or policy, its design, implementation and results. The aim is to determine the relevance and fulfilment of objectives, developmental efficiency, effectiveness, impact and sustainability. An evaluation should provide information that is credible and useful, enabling the incorporation of lessons learned into the decision-making process ...' (OECD / DAC [4]).

The research data have been derived from the application of a combination of research techniques. In our desk-based research, a survey of the academic and professional literature, together with an 
analysis of Web sites and press reports over eight years have been important secondary sources. Our consultancy work for Istanbul municipalities in the period 2002-2006 enabled us to understand the perspectives of key official actors in metropolitan and district municipalities [5]. In 2006-2007 we were engaged in participant observation in Sulukule, as invited and unpaid consultants to the Human Settlements Association and the Accessible Life Association, providing the technical community planning input for an EU funding proposal and participating in initial community planning work. Through many informal discussions with activists and related desk research, we developed our understanding of the scope and limitations of the role of NGO and community organizations in Istanbul. Most recently our ongoing MSFAU funded project has enabled us to undertake further desk research and discussions with key actors.

\subsection{0 th century regeneration solutions to the legacy of 19th century urbanization}

The term 'urban renewal' originated in the USA in the 1960s. It refers there, and in many other countries, to the redevelopment or rehabilitation of older parts of cities, including their central business areas. Urban renewal in the USA often meant the displacement of low-income communities, to create space for more profitable office, commercial, and luxury residential development, or the provision of transport facilities [6]. But across the welfare states of Europe, urban renewal originated in the housing reform movement of the late $19^{\text {th }}$ century, which emerged in response to the appalling urban conditions of industrial capitalism. Whilst property development pressures resulted in the destruction of some housing in city centers, this was minimal compared with the impact of urban renewal justified and implemented as a means of improving housing and environmental conditions of the urban poor [7].

In the context of the post-war social democratic consensus of the 1950s through to the early 1980s, urban renewal evolved as the state's response to the impact of economic and social inequality on the standard of mass housing provision. The key issue was, and still is, the gap between the quality of accommodation which low-income families could afford (the effective demand which determines market provision) and an evolving definition of minimum socially acceptable living conditions.

In the UK, attempts to bridge this gap generated two models of housing-led neighborhood renewal [7]. The first was large-scale comprehensive clearance and redevelopment. The application of this model replaced privately owned slum houses with social housing which was built, owned, and managed by local municipalities to re-house the poor at rents they could afford. But the process was top down and authoritarian. The replacement of $19^{\text {th }}$ century slums by $20^{\text {th }}$ century neighborhood designs at lower densities was held to require the clearance of large areas before re-building began. But the reduction in density meant that many families were re-housed in new, 'overspill' estates of high-rise blocks of flats on the edges of cities. This dispersal disrupted communities and created long journeys to work. The principle of expropriating private landlords in the interests of poor tenants had been politically acceptable. But when the bulldozers moved to more mixed tenure neighborhoods, there was growing opposition to expropriation from low-income homeowners who preferred to improve their homes and stay in their neighborhoods.

Furthermore, the end of the post-war boom brought cuts in public expenditure which dramatically reduced the construction of the replacement social housing. In this context, the UK government commissioned studies to assess the feasibility of private sector-led comprehensive redevelopment which would allow for the re-housing of local residents in the new houses. But these studies emphatically and predictably concluded that it was not possible to both re-house residents in private housing at costs they could afford and secure a high enough rate of return to make the investment profitable. Private sector-led redevelopment of poor neighborhoods would lead to displacement. 
Thus from the late 1960s there was a gradual shift to neighborhood rehabilitation and community development based on the state provision of financial assistance (grants and below market rate loans) to subsidize homeowners in poor neighborhoods who wanted to improve their houses [8]. In parallel, local government delivered environmental infrastructure improvements to further encourage owners' investment. During the 1970s, in the UK and other countries, local neighborhood partnerships between municipalities and residents jointly planned these modest environmental improvement schemes. This was the first significant experience of community participation in neighborhood regeneration.

Initially this was a demand-led approach, with the likelihood that those in greatest need - the poorest owners who could not afford their $50 \%$ and the tenants of landlords who 'milked' their properties by minimizing expenditure on maintenance and repair - would not be able to participate. Moreover, critics argued that the newly emerging trend of 'gentrification' in London would be magnified by this subsidized neighborhood rehabilitation process [9]. Thus Blair [10], influenced by his American experience, warned that:

'...rehabilitation is not the panacea it is claimed to be. All past attempts at rehabilitation lead to the same results: 'gentrification (the displacement of existing residents by high income groups).... for the lower paid, the immigrant, the aged and families under stress, rehabilitation is one big 'notice to quit' (p. 126).

Indeed, these limitations became increasingly apparent in the early 1970s and policy was changed to enable state resources to be more effectively targeted to the poorest households and to minimize gentrification. Higher grant rates (up to $90 \%$ of the cost of works) were made available to poor owner-occupiers on a means-tested basis. Local municipalities were given enhanced powers to compel landlords to use subsidies to improve their properties but with controlled rent increases, which existing tenants could afford. Municipalities also had increased powers to acquire voluntarily, or by expropriation, the properties of landlords who did not want to use the subsidies. They could then improve and maintain them as part of the council's social rented stock. Alternatively, they could transfer them to social housing associations which improved them and made them available at low, subsidized rents affordable for the neighborhood's poor families, together with the properties that the associations themselves acquired and improved in the area.

This more interventionist approach stimulated a combination of public and private investment that enabled some of the poorest neighborhoods in low demand areas of provincial cities to be significantly improved, with a minimum of gentrification. Moreover, it was increasingly acknowledged that although physical renewal was important, social and economic renewal was needed to address the many facets of urban deprivation. Hence, the concept of community development was introduced through a series of government sponsored pilot projects. This broadened the scope of neighborhood regeneration to include local action, which improved education and employment opportunities and access to welfare benefits and also enabled residents to develop the skills needed to campaign for and become involved in the delivery of neighborhood improvement projects.

The threat of gentrification in the UK was greatest in the favorably located Conservation Areas in London. The 'cause celebre' was the Covent Garden Conservation Area. Kocabas' research demonstrated how the worst excesses of gentrification were mitigated in the 1970s and 1980s [11]. Throughout the 1970s, the Covent Garden Community Association successfully opposed the Greater London Council's 1971 local plan for comprehensive redevelopment of the former market area and its environs for offices, shops, and relatively expensive private housing. In 1978 this plan was replaced by a pioneering, community-led plan based on the conservation of the historic buildings and the provision of social housing for local residents to minimize displacement. 
However, during the early stages of implementation, the Conservatives won control of the GLC and the advent of the Thatcher administration in 1979 resulted in a weakening of the planning system in favor of development interests. In the changed political and economic circumstances of the 1980s, the historic fabric was conserved, but much of the proposed social housing was replaced by private housing and market forces were allowed to change the area into a major retail and tourist attraction. However, Kocabas' longitudinal evaluation concluded that the displacement of the lowincome community was not the rapid and coercive process that would have resulted from the implementation of the original comprehensive redevelopment plan. Moreover, the Covent Garden community plan experience established a model that has been used particularly since the end of the 1980s as a basis for progressive municipalities restraining gentrification by giving a higher priority to the needs of low-income households. More widely still, this high profile community planning process, was one of the pioneering neighborhood initiatives which inspired the development of a generation of community planners and community architects.

In the context of the increasing impact of globalization during the 1980s, the post-war social democratic consensus gave way to neo-liberal economics and politics. Social reform-driven neighborhood regeneration programs lost their momentum as priority was given to property-led regeneration [12]. In London, gentrification gathered momentum as the changing structure of the city's economy from industrial to service sector employment led to a major increase in the size of the middle classes who expanded into hitherto working class areas with the result that '.. inner London has been gentrified with a vengeance' [13] But there was an alternative. Thus Hamnett endorses Fainstein's argument that in the 1980s more could have been done to mitigate the negative effects of fundamental economic forces, in terms of citizen participation and a redistribution of the benefits of growth $[13,14]$.

The new policy driver was the concept of urban regeneration as a process that contributes to the economic development of cities, particularly through large-scale, private sector oriented, property led-flagship projects. This shift was dominated by the regeneration of the London Docklands in the late 1980s and early 1990s for major new office complexes, luxury housing, marinas, and other leisure facilities. Later, many provincial cities initiated flagship projects, which were implemented through the 1990s. This experience created the capacity of public sector and private sector stakeholders to work in public-private partnerships, in which modest public sector resources were used to lever in major private resources. But the emphasis on flagship projects was increasingly criticized as it became clear that large mixed-use redevelopment projects brought few benefits to the poor neighborhoods in their immediate vicinity (Loftman and Nevin [15]).

Thus, from the early 1990s, the emphasis of policy shifted toward integrated area-based regeneration $[16,17]$. In the UK, neighborhood regeneration programs were enhanced as new legislation gave local authorities powers and resources to implement Renewal Areas, targeted to poor neighborhoods, using updated grant systems [18, 19]. These Renewal Areas were characterized 'housing plus' as they were more broadly based than their 1970s predecessors and had a stronger local economic component. They also often incorporated small-scale community-based redevelopment projects with provision for local re-housing, which were supported by local residents. But the crucial initiative was the development of area-based programs at the larger scale of districts with some 25,000 residents, rather than the $3000-6000$ populations of the neighborhood programs. In the UK this approach of broadly based, participatory neighborhood programs was integrated with a local flagship economic project that combined public and private sector investment to create local jobs for local people.

The 1992 Rio Earth summit prompted some academics and practitioners to re-think urban development from a global climate change perspective. For example, analysts identified the potential for 
house-building and neighborhood regeneration programs to improve the energy efficiency of the housing stock and contribute to more sustainable urban development by drastically reducing $\mathrm{CO} 2$ emissions [20]. But initially this re-conceptualization had only a very limited impact on urban regeneration practice. Nonetheless there was a developing debate about the meaning of the term 'sustainable urban development', which was gradually sharpened around the consensus that this meant that the ecological footprint of cities and towns must be reduced. However, as Couch \& Denneman [21] pointed out, government policy was ambivalent about minimizing the environmental impact of economic development - it was at best 'light green'. At local level, their sustainability appraisal of the conservation-led Liverpool Rope Walks Integrated Area Action Plan revealed the application of community planning methods such as a 'planning weekend' in which 250 people participated. The resultant projects were built into an action program, being implemented through a local partnership which aimed to ensure that the benefits of regeneration accrued to local residents and businesses, thus minimizing gentrification. But overall there was little concern for environmental sustainability, for example, there was no mention of energy efficiency or renewable energy. The standard textbook of the time [22] was similarly limited, with environmental issues being treated in traditional physical planning terms, rather than in terms of ecological footprint.

2.2 The emergence of sustainable urban and neighborhood regeneration as a contribution to the 21 st century transition to sustainable urban development

However, by building on the applications of earlier models, cutting edge practice is now developing an ecological dimension that is moving toward the implementation of sustainable urban and neighborhood regeneration.

Most cities and large towns in the UK, as elsewhere in Europe, are working to put into practice the principles of sustainable urban regeneration by developing and implementing policies and programs of projects through what can be described schematically as a 'dual approach'. This aims to provide the modern physical infrastructure demanded by the growth and re-structuring of urban economies through large-scale private sector led 'prestige projects'. But these projects are now conceived as part of a dual strategy that addresses the problems of adjacent or nearby poor neighborhoods, through public sector-led and community-based neighborhood programs that provide new and/or retrofitted homes in upgraded neighborhoods, with minimum displacement of existing residents. Furthermore, both these components aim to improve environmental conditions and reduce the ecological footprint of urban regeneration by using sustainable construction methods.

The defining characteristic of the dual approach is the integration of large-scale mixed-use economic regeneration projects with socially oriented neighborhood regeneration, through mechanisms which provide regeneration benefits to poor people in adjacent or nearby poor neighborhoods. In the UK, 'planning obligations' require house-builders to partner with housing associations to provide up to $40 \%$ of affordable social housing in each of their developments, thus creating socially mixed and thus, it is argued, more sustainable neighborhoods [23]. Other community benefits include developer funded community facilities, job training (especially in construction), and job brokerage schemes. In the context of the redevelopment of run-down social rented housing neighborhoods, this approach often means introducing a significant proportion of dwellings for sale to make the project financially viable and more socially sustainable. This process includes the provision of satisfactory re-housing of displaced tenants. However, public policies to produce a social mix can be characterized as a 'deliberate gentrification process to change the attractiveness of poor neighborhoods' [24]. The social sustainability impact of such policies - what we would term 'planned gentrification' - depends critically on the quality of the process of re-housing of displaced tenants. 
Each city develops and applies this approach in a way that takes account of local circumstances. This dual approach is exemplified by current urban and neighborhood regeneration action in London. The 2004 London Plan articulates a vision of diverse economic growth, social inclusivity to give all Londoners the opportunity to share in London's success, and fundamental improvements in London's environment and use of resources [25]. The plan established a metropolitan regeneration framework which identified 28 Opportunity Areas with major development potential. In these areas the Mayor works with the London Boroughs and private and NGO/community sectors partners to establish a sustainable (re)development program for substantial housing and employment and growth at strategic locations accessible to public transport. This partnership process agrees with the scale of developer financial contributions to the provision of community infrastructure, affordable housing, and training programs, all of which are designed to minimize gentrification. The implementation program is integrated with the implementation of the socially oriented and community-based local neighborhood renewal strategies of the London Boroughs. This dual approach stands in sharp contrast to the laissezfaire approach to docklands regeneration in the 1980s and early 1990s.

The 2008 London Plan revisions gave first priority to action to mitigate the impact of climate change by reducing carbon emissions from the city's buildings and transport systems [26]. This priority is being increasingly built into urban and neighborhood regeneration programs. Thus, in the London Borough of Southwark, a hallmark of the recently agreed development strategy for the Elephant and Castle Opportunity Area is its very high energy efficiency standards and high level of usage of renewable energy [27]. At the neighborhood level the former (now completed) Bellenden Renewal Area is a pilot low carbon community project [27].

In conclusion, this analysis has shown how the application of successive regeneration models has contributed to the development of contemporary approaches to sustainable urban regeneration. Thus cities in the UK, as elsewhere in Europe, are currently working to deliver sustainable urban regeneration by developing and implementing programs of projects through variations of a dual approach which:

- provides the modern physical infrastructure for city wide economic development in medium- and large-scale commercial redevelopment projects in strategic locations, which are mainly private sector financed, often mixed use, and implemented through strategic partnerships;

- addresses problems of poor physical and social conditions in deteriorating neighborhoods, often those close to the strategic locations, community-based neighborhood programs that provide new and or retrofitted homes in upgraded neighborhoods, but with minimum displacement of local people and which are implemented through neighborhood partnerships; and

- links the two processes by imposing planning obligations on the large-scale commercial developments that generate benefits for community-based neighborhood programs.

Both components are giving increased priority to reducing the carbon footprint of urban regeneration by using sustainable construction methods and developing 'carbon conscious' regeneration partnerships.

Istanbul has recently started to address the challenge of developing its version of sustainable urban regeneration, but with little previous experience to build on, other than the 'top-down' state funded, urban motorway dominated, prestige projects of the first Mayor of the city in the 1980s [28, 11]. However, Turkish analysts and decision makers have the opportunity to learn from both the successes and the failures of the historical and contemporary experience of European cities. In the context of the European harmonization process that began in December 1999, when Turkey was accepted as a Candidate Country, a multi-faceted technical exchange process has been developing. 
The various components include cross-national academic research and teaching and EU funded projects linking Turkish municipalities and NGOs with their counterparts in Member States. The position has now been reached where the goal of sustainable urban and neighborhood regeneration has been adopted by the 2009 National Urban Commission in the following terms:

'....sustainable urban regeneration is a public sector led process which uses spatial planning to guide physical development so that it supports the economic development of cities, improves living conditions for those in the poorest and most earthquake threatened neighbourhoods and improves the environmental performance of the city, particularly by reducing carbon emissions' [29, 30].

The paper now turns to a review of the progress during the past decade toward delivering sustainable urban regeneration in Istanbul, with particular reference to the Historic Peninsula.

\section{URBAN REGENERATION AND THE CONSERVATION OF THE HISTORIC PENINSULA}

This section establishes the context and rationale for the Sulukule case study in terms of an analysis of the emergence of urban and neighborhood regeneration since the early 2000s. This process was driven by the acceptance of the need for regeneration as a component of earthquake mitigation action and the impact of the ongoing restructuring of the city's economy. Both these drivers have contributed to the re-shaping of the long established processes of urban conservation in the Historic Peninsula, which were seen by UNESCO to be failing badly.

\subsection{Sustainable urban regeneration for Istanbul: challenge and response}

During the past decade, Istanbul planners and decision makers have become increasingly aware of the dual challenge of unsustainable urban development: accelerating urban decay and continuing, property market-driven urban growth. Hundreds of deteriorating neighborhoods are the legacy of a period of explosive urban growth since the 1970s, which saw the city's population increase from $2 \mathrm{~m}$ to $10 \mathrm{~m}$, mainly through immigration from rural Anatolia. Huge swathes of mainly informal and illegal housing development engulfed the historic central area - see Fig. 1.

\section{ISTANBUL METROPOLITAN AREA: HISTORIC DEVELOPMENT STAGES}

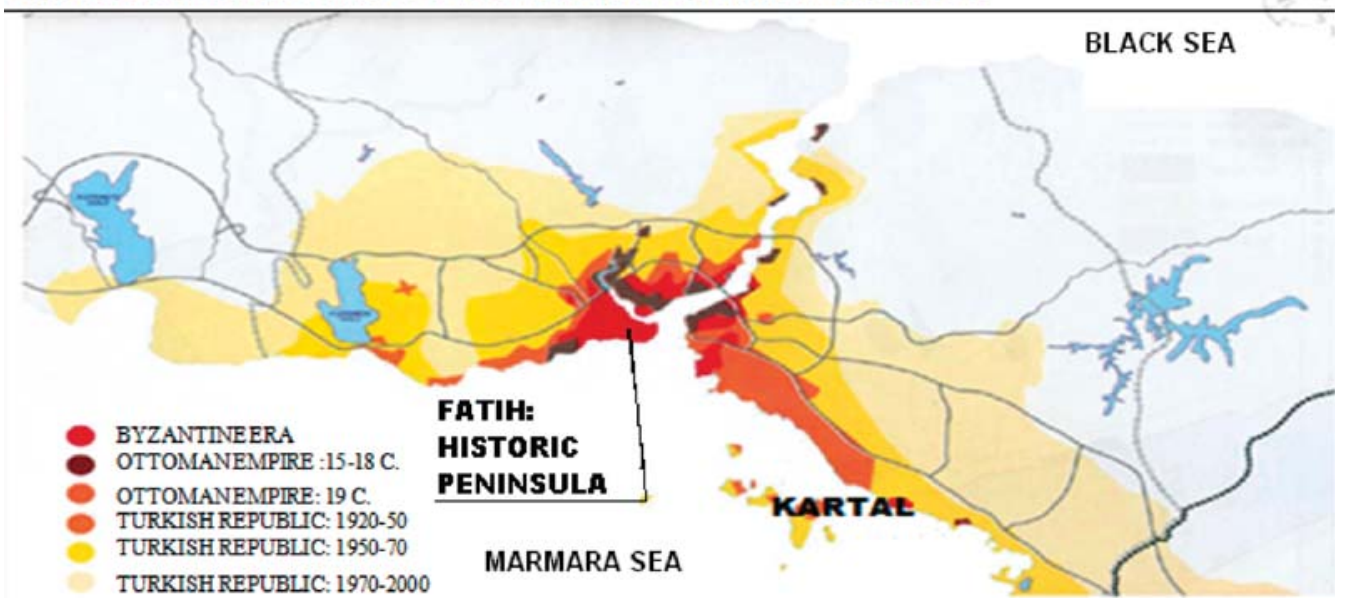

Figure 1: Growth of Istanbul (source: adapted from IMP [31], p. 12). 
Until the early 1980s, much of this growth was in the form of self-build 'gecekondu' neighborhoods of mainly single storey dwellings, often with a garden attached. Then, in the context of economic liberalization, population growth was housed in thousands of illegal, speculative developments of 4-6 storey blocks of low standard concrete flats, constructed illegally to low standards, with poor services and minimum environmental standards. In parallel, many of the original squatter neighborhoods were redeveloped and the original low density dwellings were replaced by the same type of high density 4-6 storey flats. However, much of this housing was built on earthquake vulnerable land.

The 1999 Marmara earthquake killed 17,000 people and the destruction or damage of 300,000 dwellings, commercial buildings, and infrastructure caused losses of 6 billion USD. Subsequent research pointed to the likelihood of a much more severe earthquake within 30 years. This estimated that 170,000 buildings ( $18 \%$ of the city total) will be heavily or moderately damaged, which will cause some 90,000 deaths and 135,000 serious injuries. The then Mayor of Istanbul described the earthquake as a wake-up call (Kocabas \& Gibson [32]). To mitigate the impact of the earthquake, more than a million dwellings will have to be demolished or structurally upgraded in 400 neighborhoods, the homes of 5.2 million people (JICA \& GIMM [33]). This pointed unambiguously to the need for large-scale neighborhood regeneration programs: life-threatening neighborhoods are the antithesis of sustainable development.

The increasing impact of globalization in the late 1980s precipitated de-industrialization, which in some parts of the city left a legacy of large semi-derelict land, often in the midst of poor neighborhoods. But the continuing re-structuring and growth of the city's economy through the 1990s created increasing demand for modern office space, new middle and high income housing, retail, leisure, and cultural and tourist facilities. These demands generated speculative development pressures, as national investors were joined by international investors in promoting profitable redevelopment projects close to the historic centre. Large mixed-use redevelopment projects began to appear, often in locations badly served by public transport and surrounded by poor neighborhoods, which received none of the benefits of regeneration and in some cases faced gentrification pressures. This development pressure resulted in a variety of high profile projects being proposed in key locations in Istanbul, such as the Dubai Towers project and proposals for Galata Port and Haydarpasa (Ozaydin and Kocabas [34]). In parallel, more and more new housing for the expanding middle class was constructed in the forests and water catchment areas to the north of the city (Gorgulu, et. al. [35]). There was an increasingly clear need to guide these development pressures in ways that would deliver more sustainable outcomes.

Thus the dual challenge of sustainable urban and neighborhood regeneration facing Istanbul is analogous to that facing London: how to guide mixed-use economic regeneration projects to appropriate strategic locations, through processes which ensure that some benefits to accrue to adjacent or nearby earthquake mitigation-led community-based neighborhood regeneration programs. This suggests that there is scope for adapting the generic models illustrated from the UK experience discussed above, but with the adaptation taking full account of the specificities of Turkish urbanization processes. Since the early 2000s, it has been increasingly acknowledged in Istanbul that the changing processes of urbanization are presenting problems and opportunities which require government intervention through spatially targeted urban and neighborhood regeneration programs which would be the equivalent of those in many EU cities.

The initial response to the challenge was a series of mainly GIMM funded research and development projects, which built on the JICA study. This work developed the urban policy agenda and drew on the experience of EU countries, at a time when the EU harmonization process began to strengthen internationalist perspectives in the Turkish planning community. 
The informal Istanbul Earthquake Master Plan emphasized the importance of making earthquake mitigation part of the wider process of urban governance, in particular the importance of integrating it with the reform of spatial planning and the development of major urban regeneration programs [36]. In parallel our project explicitly focused on identifying the principles of urban and neighborhood regeneration as practiced in the UK and other EU countries, including the emerging dual regeneration strategy in the Draft London Plan. The study drew on this experience to develop an outline sustainable neighborhood regeneration strategy for Istanbul, which embodied the first attempt to develop a Turkish version of the dual approach $[2,29,37]$. These studies marked the inception of the ongoing debate about the purpose, scope, and desirable outcomes of urban regeneration in Istanbul. Further commissioned research by Istanbul universities developed key themes, particularly the need to integrate land use planning and regeneration through strategic development frameworks and action plans [38]. This theme was taken forward in the Zeytinburnu Pilot Project, which produced a strategic development framework and a series of action plans [39], which in turn led to the production - but behind closed doors - of urban design proposals for neighborhood redevelopment.

Urban regeneration was a major issue in the preparation of formal strategic Master Plans in 2005-2006, which explicitly aimed to promote a more sustainable pattern of development, directing growth away from the north to new sub-centers to the west and east [40]. Drawing on the London experience, the 1:25000 Plan included the identification of approximately 50 strategic regeneration sites that are intended to accommodate much of the city's economic growth. There has been some progress toward implementation of some of these key sites. Thus a process has emerged which starts with the identification of the sites, followed by the preparation of statutory 1:5,000 and 1:1,000 plans, then the preparation of a design guide and, in parallel with these processes, the initiation of a partnership approach involving key stakeholders. This process of moving from planning to implementation is most advanced in Kartal [11] to the east and Kucukcekmece to the west [41].

But there were no specific proposals for identifying priority neighborhoods and with the exception of Kucukcekmece [41], there has been no progress in the regeneration of poor and earthquake-threatened areas built in the 1970s and 1980s. A major reason for the lack of progress was the failure of central government to finalize the 2005 Draft Urban Regeneration Law. It is in the Historic Peninsula where neighborhood regeneration has moved from planning to implementation, in processes set in train by new conservation legislation.

\subsection{The Historic Peninsula at risk}

The evolving debate about the scope, purpose, and methods of regeneration in Istanbul generated the proposition that urban conservation should be re-conceptualized as a component of sustainable urban regeneration. This was in part prompted by cross-national comparative research and in part by the JICA study's revelation that the historic districts were some of the most vulnerable to earthquake damage. In this perspective:

'The contemporary challenge is to find ways of attracting higher levels of public and private investment into the historic districts, in ways that equitably meet the needs of their half million (mainly poor) residents and preserve the fabric in ways that also contribute to the city's economic development. The poor should share the benefits of conservation, for example by accessing tourist industry jobs and alternative housing, and they should participate fully in determining the future of their neighbourhoods, which are the basis of their quality of life, yet are at the same time globally significant heritage resources' ([42], p. 120).

This view did not initially find favor with those who saw urban conservation as a specialized and relatively autonomous activity and were skeptical about the rights or capacity of the poor to remain 
as custodians of cultural heritage. But it is now conventional wisdom to refer to conservation-led urban regeneration [43].

But the future of the Historic Peninsula was also at risk because of the ongoing ineffectiveness of urban conservation processes and the resultant continuing erosion of the historic built environment. In summer 2003, UNESCO threatened to transfer the Historic Peninsula World Heritage Site to the List of World Heritage in Danger. The continuing failures of the conservation authorities prompted UNESCO technical team visits in 2007, which led to a repeat threat in the year the city won the designation of European City of Culture 2010, and 2008, which noted some progress with the development of an Area Management Plan but condemned the implementation of the Sulukule Renewal Area Plan.

Also in 2005 the Istanbul Historic Peninsula Conservation Oriented Development Plan (IHPCODP) was approved and the government announced a 100 million USD allocation for the restoration of the City Walls. In the following years the GIMM's Museum City Project developed a digital inventory of all the historic buildings in the area. Urban design schemes were prepared also behind closed doors - for several historic neighborhoods in the east of the Historic Peninsula in the Eminonu Municipality. These included proposals for significant demolition and rebuilding to the Ottoman street plan with replica Ottoman house types - an approach that dismayed the UNESCO teams and the majority of the city's conservation experts. However, the debate was initially academic as there were no mechanisms that would enable the CODP to be significantly implemented.

In parallel the GIMM carried out the Fatih Earthquake Risk Urban Regeneration Project during 2006-2008. This project prepared the Fatih District Emergency Action Plan, based on the approach developed by the Zeytinburnu Pilot Project. Thus it focused on the first phase of implementation - demolition of highest risk buildings, opening up of evacuation corridors and emergency gathering areas, etc. The project also prepared the Fatih District Development Action Plan which identified major development opportunities and constraints and developed financial and organizational models. Detailed earthquake risk assessment identified the 10 highest risk neighborhoods all in the western half of the Historic Peninsula. Neighborhood Action Plans were prepared for these areas, which were based on urban design projects with three different density options for redevelopment. But all this work was also 'behind closed doors' with little reference to the needs and affordability of local people and no community participation. The lack of any effective implementation processes meant that these plans never got off the drawing board [3].

But this was not the case with the second and parallel neighborhood regeneration program in Fatih, which resulted from the coming into operation of Conservation Law 5366 in June 2005. The aim of the legislation is to redevelop and restore deteriorating designated Conservation Areas, by establishing residential, commercial, cultural, and tourism related uses, together with enhancing public infrastructure. In addition, preventative measures are to be taken against natural disasters and historical and cultural property is to be conserved. The legislation provided new powers and significant resources to enable district municipalities to designate Renewal Areas in historic districts, for which they could develop Renewal Area Plans and implement them through a phased program of Renewal Projects. These powers were exercised by a Renewal Board comprising government appointed experts (planners, architects, building conservationists) - working in partnership with District Mayors and TOKI.

A pre-condition for the implementation of new legislation is political will. In 2004, the newly elected AK Party (conservative- pro Islam) Mayor was faced with a recently approved GIMM Conservation Oriented Development Plan and little prospect of follow-up neighborhood action, as 
the GIMM Museum City Project was focused on the eastern part of the Historic Peninsula in the adjacent Eminonu Municipality. However, funds had been allocated for the conservation of the City Walls, which form the west, south (Bosphorus), and north (Golden Horn) boundaries of the Municipality and are part of the World Heritage Site. But he inherited the UNESCO de-listing threat with its related political, bureaucratic, and technical complexities, together with the prospect of continuous negative publicity. In line with common mayoral practice he spent the first year of his new term identifying his action priorities. Inevitably, conservation was a priority issue. He was aware that new legislation was in the pipeline which would give him an unprecedented opportunity for action.

In this context the Mayor developed a phased, conservation-led neighborhood regeneration strategy targeted on 15 areas, most of which are adjacent to or nearby the City Walls - see Fig. 2. Sulukule was the first to be targeted, and to date, the only one which has been implemented.

Over time, upgrading these neighborhoods in tandem with restoring the walls would have a major, positive image impact and provide the basis for drawing tourists west from the major sites in Suleymaniye. Given the dominance of the AK Party, the Mayor could reasonably expect two terms and a significant impact could be expected within that time span. The Mayor's proactive approach was further indicated by the fact that he was the only Mayor to formally support Istanbul's successful, NGO-led bid in May 2006 to be the European Capital of Culture 2010.

However, critics argue that an underlying issue was that the program of Renewal Areas would contribute to the delivery of a pro-Islamist vision embodied in the Museum City Project's proposed recreation of an 'Ottoman Historic Peninsula', in the interests of the growing, conservative, and Islamist-oriented Istanbul middle class [45]. The substantial redevelopment of the target neighborhoods to much higher housing and environmental standards would enable the better-off members of the community to stay in the area and be joined by like-minded newcomers. The realization of such a vision would require the neighborhood regeneration program to evolve into the planned gentrification of the Historic Peninsula.

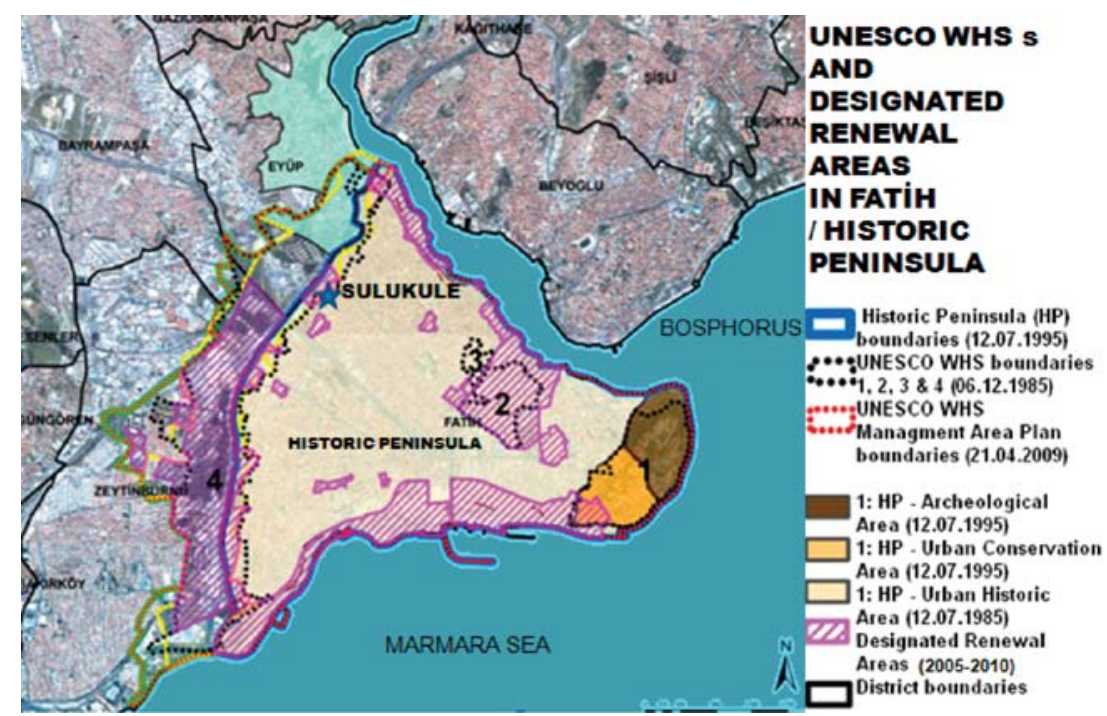

Figure 2: Designated Renewal Areas in Historic Peninsula including Sulukule under the Conservation Law no. 5366: 2005-2010 ([44], p. 21). 


\section{SULUKULE RENEWAL AREA: THE RECORD AND THE CONTROVERSY}

In November 2005 the Mayor formally proposed Sulukule as the first Renewal Area - see Fig. 3. This proposal was approved in January 2006 by GIMM Council and by the central government Council of Ministers in April. Then in July, the Fatih Municipality, TOKI (the government's housing construction agency), and GIMM signed the Renewal Area Protocol which launched the Renewal Area planning and implementation process. Later that month, the Sulukule Roma Culture.

Development \& Solidarity Association was formed and declared its outright opposition to the redevelopment of the neighborhood. This section analyses the implementation of the Renewal Area Plan which led to the demolition of the neighborhood and the destruction of its Roma community, despite the efforts of civil society organizations to establish and secure the implementation of an alternative plan.

\subsection{Neighborhood profile, key actors, and parallel planning processes}

Located alongside and within the Theodosian Walls, Sulukule was one of the poorest neighborhoods in Fatih and this was one of the main official reasons for it being selected as the first Renewal Area see Fig. 3. Its two and three storey dwellings, often grouped around informal courtyards, were built to high densities in an informal layout. There was minimum provision of basic services and often shared basic facilities. In 2005, some 5,000 people lived in the area, 3,500 of whom were Roma. Interspersed within the overcrowded houses were a few substantial historical buildings which, with the monumental City Walls, constituted the neighborhood's tangible cultural heritage. But the neighborhood was also host to unique intangible cultural heritage, in that it had been the home of a 1,000-years-old Roma community that was established as a center for music, belly dancing, eating, and fortune telling in Ottoman times. This tradition survived until the 1990s when the entertainment houses were arbitrarily, and in some cases, violently closed down by the police, ostensibly on the grounds of public safety. This destroyed much of the neighborhood economy overnight as some 3,000 people lost their livelihood. Many people were left reliant on very low paid and insecure jobs. Many musicians became street vendors. Informal systems of credit helped sustain bare subsistence and shared adversity strengthened community solidarity, but with self-sufficiency came isolation. The former entertainment houses were rented out as very cheap accommodation, which inevitably attracted more poor immigrants to the neighborhood. There was an apparently related increase in the
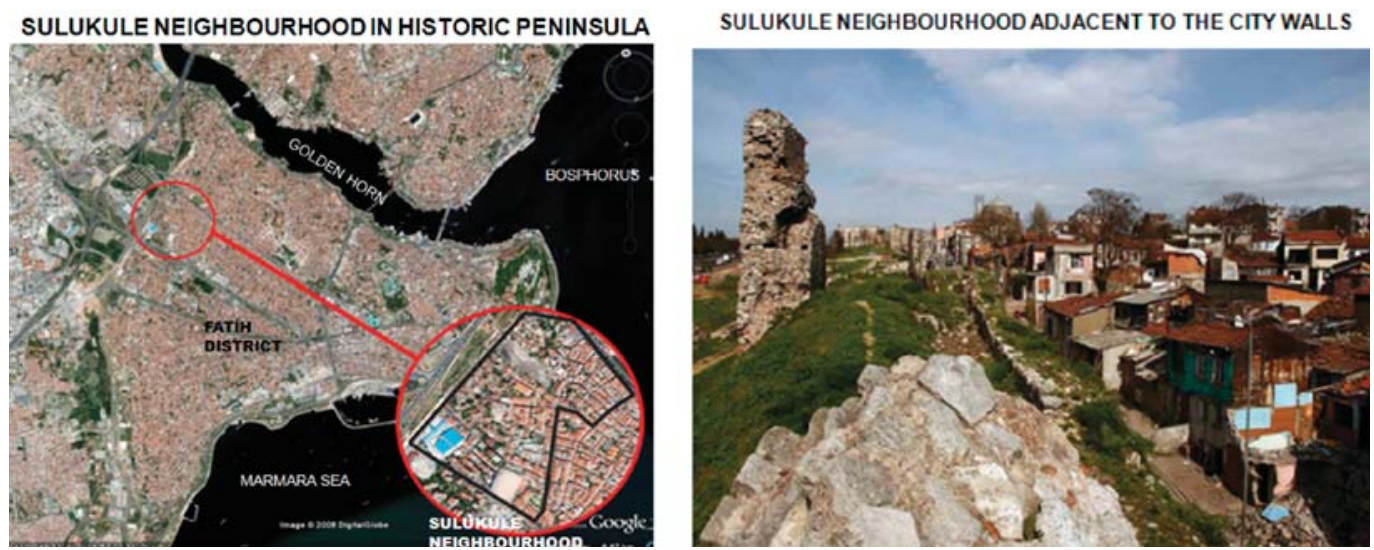

Figure 3: Location of Sulukule Renewal Area (July 2005) and a view over the City Walls [46, 47]. 
small minority of local people involved in drug abuse and prostitution. Sulukule was left to decay until the Law 5366 presented opportunities for drastic municipal action.

The Roma provided entertainment for the Istanbul middle classes but this did not prevent negative stereotyping which was used to justify police harassment. This stereotyping was reflected in a Fatih Municipal Council meeting in December 2007. An opposition CHP (Republic Party) spokesperson referred to the collapse of the entertainment sector and expressed the view that neighborhood regeneration should provide new employment opportunities. He was met by a response from ruling AK Party politician that '... that place has nothing to do with entertainment. Thirteen, 14 and 15 year old girls are forced into prostitution there. ... It is a hotbed of prostitution. It is the bad face of the entertainment sector. We have to change that place' [48]. These stereotypical views were apparently echoed by none other than the former Mayor of Istanbul and now Prime Minister R. Tayyip Erdogan who is reported to have ordered the Fatih Mayor 'to clean the place up' [45]. This was indicative of what many activists and analysts believe to be the underlying reason for Sulukule not only being the first Renewal Area, but also for the choice of comprehensive redevelopment, rather than rehabilitation, as the basis of neighborhood regeneration.

The regeneration process to date can be analysed in terms of two parallel planning processes - see Fig. 4. The formal 'official planning, urban design, and implementation process' was lead by the Fatih Mayor, working in Partnership with TOKI and the newly constituted Renewal Board. This official process was focused on the preparation and approval of the Renewal Area Concept Plan and the Renewal Area re-building projects. The parallel informal community planning processes attempted to prepare a substitute alternative community plan. The main actors were the NGOs and a neighborhood organization working with a loose network of volunteer human rights activists, planners, architects, academics, and students - the Sulukule Platform.

\subsection{Renewal Area planning, urban design, and implementation processes}

The July 2006 Protocol set in motion the application of the generic 'comprehensive clearance and redevelopment model' of neighborhood regeneration. It established formal aims for the Renewal Area which can be summarized as follows: to improve the quality of life of inhabitants, to conserve world heritage (both tangible and intangible), to support local socio-cultural and economic development, to ensure public participation, and to integrate the neighborhood into the city as a modern, inhabitable, and sustainable place [49]. But within this list was the potential conflict between conservation and the development implied by the aims of integration and modernization: from the outset the central issue was the balance to be struck between them. The Protocol committed the Municipality and TOKI to the comprehensive redevelopment of the neighborhood requiring the demolition of 571 of the 621 dwellings and all the 45 offices in the area, which as a means of achieving the aims meant that the balance was weighed heavily in favor of development interests. The Municipality's responsibilities were to secure the land for development (by negotiation or expropriation) and to demolish the old buildings. TOKI's responsibility was to redevelop the resultant large site and provide alternative housing in Tasoluk, some $40 \mathrm{~km}$ away. After the Protocol was signed, commissioned architects prepared the RA.

Concept Plan and 17 housing projects to meet the brief of 'one for one' replacement of dwellings and offices. But the modern Sulukule was designed completely 'behind closed doors', although at the end of the year the Municipality announced that the housing would be built in the 'classical Ottoman Turkish architecture style'. 


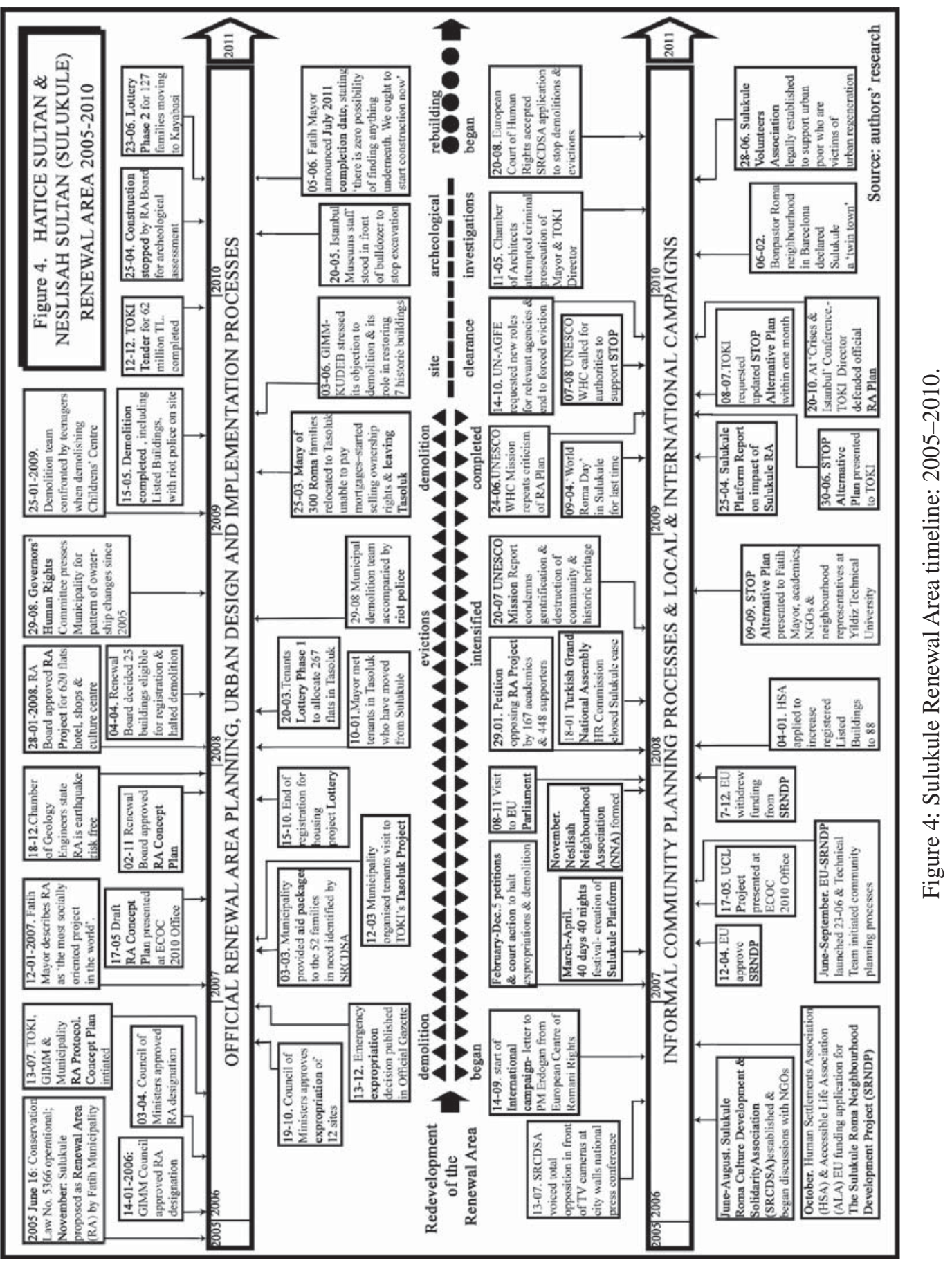


In December 2006 the Municipality secured approval, under Law 5366, for the compulsory acquisition of all the properties in the Renewal Area. Residents were then sent a letter that stated that their neighborhood was going to be demolished and redeveloped to provide higher quality housing. Armed with the right to purchase by compulsion if eventually necessary, Municipality staff began to negotiate with individual homeowners to secure their 'voluntary' agreement to participate in the project by agreeing to exchange their dwelling for a new one in the Renewal Area. In addition, a 'housing benefit' of 400TL per month was payable to owners if they stayed in their house until they moved to their new dwelling. However, only about $10 \%$ of homeowners were willing and able to buy into the redevelopment project on the basis of the compensation they would receive and their ability to service a 15-year mortgage for the balance of the price. However, when they took possession of their new house, they would have the option of selling at a significant profit, as there were no restrictions on re-sale.

But the Municipality offered only TL 500 per sq m compensation, compared with values in the surrounding neighborhoods of TL 2000 per sq $\mathrm{m}$. This offer did not take into account the 'market value uplift' that would be realized through the redevelopment process. Not surprisingly, many owners refused the Municipality's offer and demanded a higher level of compensation. The valuation gap inevitably generated property speculation. Some residents were approached by a third party who offered a better price, which they accepted. Others, becoming aware of the opportunity for a better price, put their homes on the market and sold on. By April 2009, over 65\% of owners had sold their property to third parties who agreed to make the dwelling available for demolition when needed, by evicting tenants as necessary. Critics allege that the Municipality actively encouraged this speculative process and there were allegations of AKP members buying houses in the neighborhood [50]. The increasing momentum of this piecemeal process of negotiation and transfer of property rights was accompanied by a piecemeal demolition of empty properties marked by a cross (in a manner evocative of the bubonic plague) and often accompanied by forced eviction. This prompted a precipitate decline in neighborhood conditions, putting further pressure on owners to sell. The overall outcome was that within two and a half years the Municipality reached agreements with 530 of the 620 property owners who were given the right to a new home in the Renewal Area [51]. Tenants who had no property rights were given the opportunity to become homeowners in Tasoluk or they were expected to re-house themselves when their homes were due to be demolished. Many of the very poorest tenants lived virtually rent-free in the former entertainment houses. Research by the Sulukule Platform revealed that $60 \%$ of tenants paid less than TL200 (approximately 100 Euros) per month [48]. The pressure to accelerate property acquisition and demolition was driven by the fact that to start rebuilding to a modern new layout, the Municipality needed complete ownership of at least a significant part of the neighborhood. This pressure drove the re-housing process. Tenants who agreed to go to the TOKI estate in Tasoluk were given until October 2007 to register for the lottery through which individual families were allocated flats. The municipality organized visits to the estate and the first lottery allocated some 300 flats at the end of March 2008 [51]. As re-location got underway, the rate of evictions and demolitions intensified (now with riot police in attendance), as did the pressure on families to reach an agreement with the Municipality. But faced with relatively high mortgage payments of 275-475 TL (132-246 Euros) per month, high fuel bills and maintenance costs, and costly access from the remote location to employment, the majority of tenants concluded that their prospective new home were unaffordable. Thus of the 300 or so tenants granted leases in Tasoluk, two-thirds sold their entitlements and moved elsewhere and only one-third actually moved to Tasoluk. Of those who moved, the majority sold after arriving in Tasoluk. In April 2009 it was claimed that only 27 Sulukule families were living in Tasoluk [51]. 

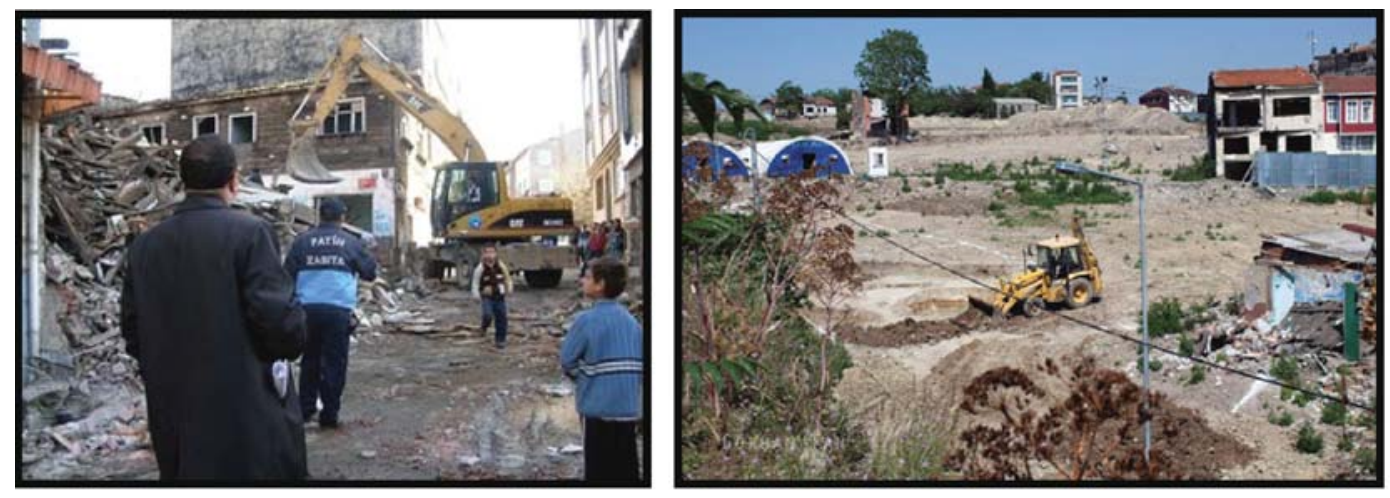

Figure 5: Sulukule demolition phase [52].

\subsection{Community planning processes and local and international campaigns}

Residents had no involvement with the development of the Protocol and the decision to redevelop the area which, ostensibly at least, had been justified by a limited analysis of physical conditions and property ownership, with no reference to the needs of the local community. The acquisition, re-housing, and demolition processes were authoritarian and bedeviled by the Municipality's poor communications - see Fig. 5. It was in this situation that energetic and innovative, but ultimately unsuccessful, attempts were made to apply the generic 'neighborhood rehabilitation and community development model', through parallel processes of embryonic community planning and campaigning to stop the official processes - see Fig. 4.

The initial announcements of the Fatih Mayor's proposals prompted the formation of the Sulukule Roma Culture Development and Solidarity Association. In July 2007, at a televised press conference alongside the City Walls, Sukru Punduk, chair of the association read the Roma community's declaration of opposition to the Renewal Area proposals;

'As a consequence of this project we will have to leave the places in which we have lived for centuries. If the Municipality really wants to preserve Sulukule, we can be offered technical and financial assistance for the renovation and repair of our houses. We wish to have Sulukule revived and become a positive feature of Istanbul's cultural and entertainment life; so that we can have employment opportunities generated for the young-elderly-women-men, simply everybody' ([48], p. 43).

This encapsulated a very different vision of the future of Sulukule and set the parameters for all subsequent efforts to develop an alternative plan. The first initiative was cooperation with the Accessible Life Association (ALA), an NGO with a mission that included supporting Roma communities in Istanbul and the Human Settlements Association (HSA), an NGO focused on promoting participatory planning and urban conservation in Istanbul. These NGOs and the Association formed a partnership and recruited us as volunteers to help them to submit an application to the EU delegation in Ankara for the funds to develop a community-based alternative plan for the Renewal Area. This project - the Sulukule Roma Neighborhood Development Project - was to fund a technical assistance team to work intensively over a year with the local community and the Municipality to create a community planning process that drew on the experience of neighborhood regeneration in EU cities [53]. The proposal was submitted in October 2006 and a grant of 139,000 Euros was approved in April 2007, subject to final administrative agreements. 
In the meantime these NGOs contributed to 'Sulukule 40 Days and 40 Nights', a program of events in April 2007 designed to celebrate Roma culture and undermine the negative stereotyping of the Roma community of Sulukule. This Roma support mobilization process evolved into an Istanbul-wide, loosely coordinated NGO network - the 'Sulukule Platform' - to campaign to stop the Renewal Area Plan and give time to prepare an alternative. The NGO partnership then worked with a University College London student project led by academics with strong links to United Nations human rights organizations. This brief project prepared an initial baseline study using secondary data and stakeholder interviews which demonstrated the case for, and outlined the potential content of, a community-based and rehabilitation-led alternative plan [54]. The presentation of this study at a Sulukule Platform meeting in May 2007 held in the new offices of the ECOC 2010 agency was accompanied by the first public presentation of the Renewal Area Concept Plan by the Municipal staff [57]. After this meeting, the Sulukule Platform initiated various attempts to establish a formal Protocol for collaborative working with the Municipality, but without success. From this point, the Platform concentrated on campaigning and legal actions.

In parallel, the ALA-HSA team to be funded by the EU was established as an informal working group. Initial capacity building focused on developing a shared understanding of community-based neighborhood regeneration and programming of work. A dialogue was established with the Municipality's technical team. This produced a modest but still inadequate increase in the redevelopment density and a commitment for Municipal staff to share an office in the neighborhood. Although the grant contract had yet to be signed, the EU Ankara office allowed the project to be formally launched at the end of June $[58,59]$. Continuing on a limited voluntary basis, a community profiling survey was designed and undertaken during the summer by members of the team, coordinated by a planning academic as part of his $\mathrm{PhD}$ research. Amongst other things, this survey documented for the first time the number and composition of tenants, the importance of the close-knit kinship ties, and revealed that the income of more than half the households was less than the monthly mortgage payments in Tasoluk.

The parallel campaigning, loosely coordinated through the Platform, was focused on the argument that the human rights of the Roma residents were being violated by them being forced to leave their homes. It was this issue that mobilized support from a range of international organizations and had been raised at the outset by a letter from the European Center for Romani Rights to Prime Minister Erdogan in September 2006. But in January 2008, the Turkish Grand National Assembly (Parliament) Human Rights Commission concluded that '...there was no evidence of Roma culture
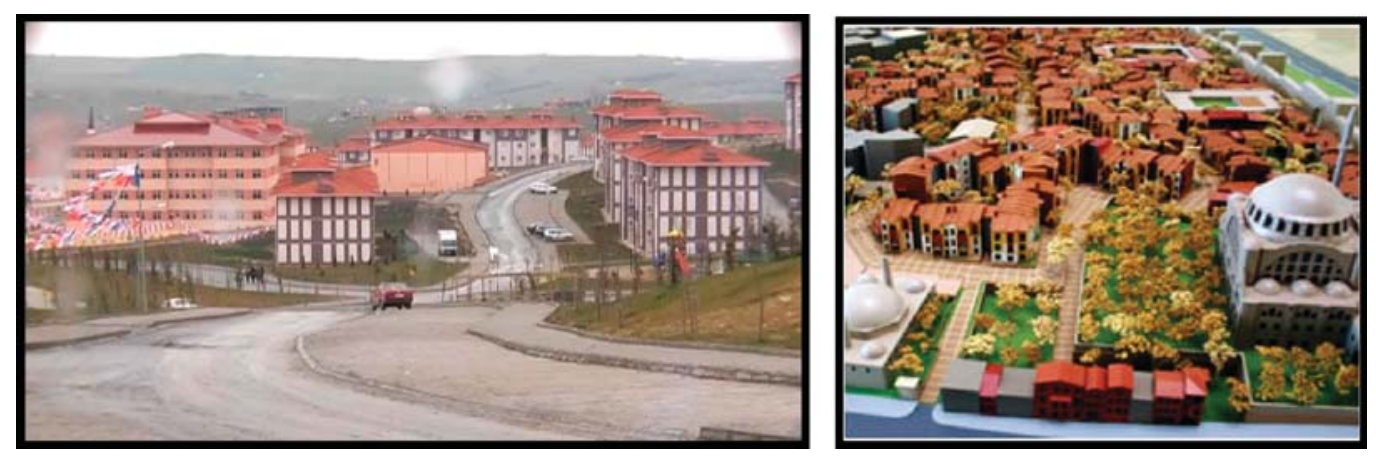

Figure 6: TOKI Tasoluk apartments $40 \mathrm{~km}$ away from the Sulukule Renewal Area and the scaled model for the proposed project $([55,56])$. 
being destroyed and human rights violation in Sulukule' and closed the case [60]. Another path of resistance was through the courts. During 2007, five court cases and petitions were initiated by or on behalf of the Association both to the Turkish courts and then to the European Court of Human Rights. Faced with the publicity generated by this extraordinarily high profile campaign the Renewal Area Board, which is responsible for approving the Renewal Plan, felt obliged to hold a hearing in the neighborhood in November 2007. The Board said they would consider residents' views before approving the Plan but they approved the Plan on the next working day. The following week, ironically after months of lobbying, the case for and against the Plan was debated by the Mayor and the NGOs at a meeting in the EU Parliament - see Fig. 4.

In November 2007, the task of preparing a community-based alternative plan was made yet more complex with the formation a second, non-Roma neighborhood association that supported the Plan. This gave public expression to the split in the community, with a sizeable minority of Islamically oriented residents supporting the view that the neighborhood had degenerated and needed to be cleaned up [45]. However, at the same time the evolving capacity to develop a community planning process suffered a major setback. The AHA-HSA partnership had been beset by internal conflict about how the EU grant should be administered and for several months had allowed this to delay signing the contract. This impasse caused the EU delegation to withdraw the grant offer in December 2007, ending all prospects of the minimum level of sustained and experienced technical aid needed for community planning being available to Sulukule.

But the struggle continued and in January, the Sulukule Platform volunteers organized a petition opposing the approved Renewal Area Plan, which was signed by 167 academics and 448 supporters. In a change of tack they took the Municipality to court in an attempt to increase the number of listed buildings to the point where Renewal Plan would have had to go back to the drawing board. But this was only partially successful as a few buildings were added and their demolition stopped, but in some cases, listed buildings were illegally demolished. The accelerating destruction prompted strong and sustained criticism from the UNESCO World Heritage Commission in their reports in mid-2008 and mid-2009, which condemned '.. the destruction of tangible and intangible cultural attributes and the dispersal of communities through a programme of planned gentrification by local authorities ... in a development rather than a conservation project' [61]. A regrouping of the planning and architecture volunteers created the STOP initiative led by other MSFAU academics and the Chambers of Architects and Planners. In Autumn 2008, an outline plan was produced which preserved the historical street pattern, proposed the inclusion of smaller and cheaper dwellings to meet the needs of those who have left as well as those who have bought into the new project and proposed halting speculation by restricting re-sale of new houses for five years. They frankly described this as an advocacy plan, rather than a community plan as there was no direct involvement of local residents. It was argued that as demolition was reaching its final stages, an archaeological assessment should be undertaken and the time taken should be used to modify the approved Plan. The alternative plan was presented to the Mayor, NGOs, and neighborhood representatives, but received a cool reception from the Municipality. An update of the Plan 'within two weeks' was requested by the Director of TOKI in July 2010 and was provided, but subsequent discussions failed to secure changes in the proposed housing.

In December 2009 contracts were let for the first phase of rebuilding of Sulukule. But there were delays as organizations protested the destruction of the archaeological heritage. Old buildings with shallow foundations which had protected archaeological remains were about to be replaced by the much deeper foundations of the new development, especially the underground car park. But the first phase of housing is now well underway with a target date for completion of July 2011 and it is likely that the full redevelopment program will be implemented. Thus an unprecedented campaign to stop 
the implementation of an unprecedented Renewal Area Plan generated intensive debate which achieved an international profile. But this intense activity yielded only token adjustments to the official plan and the newly established implementation processes.

The explanation lies in the fact that the parallel planning processes were working to realize two competing and very different visions of the future of Sulukule. The Mayor's redevelopment vision involved the application of the generic 'comprehensive clearance and redevelopment model'. In the traditional 'top-down' Turkish governmental system and culture, this vision and process had been set in stone at the time of the Renewal Protocol. Community planning did not get beyond an embryonic stage as it was entirely dependent on volunteers. Thus by the time the basic application of the "neighborhood rehabilitation and community development model' had been formulated, it was impossible for the authorities to row back from comprehensive redevelopment for both practical cost reasons and political reasons.

\section{IMPACT ON SULUKULE AND PROSPECTS FOR SUSTAINABLE URBAN REGENERATION IN ISTANBUL}

This section first evaluates the ongoing Sulukule neighborhood regeneration process in terms of the extent to which it has fulfilled its objectives and its impact on Sulukule as a place and on the people who were living there when the process began. Then the wider evaluation assesses the likely impact on the future of the Historic Peninsula and on the prospects for sustainable neighborhood regeneration in Istanbul. Both levels of evaluation are developed with reference to the generic models identified earlier in this paper.

\subsection{Sulukule Renewal Area five years on: impact on place and people}

Since 2006, the Sulukule neighborhood has been almost totally demolished and temporarily de-populated. The Mayor has set a target date 2011 for completion of the first phase of rebuilding, so it is likely that he will have achieved his objective of redeveloping Sulukule within a six- or seven-year period, which is reasonable in comparison with experience in other countries. But the Sulukule Platform's assessment of the project against its stated aims argues that it has failed to improve the quality of life of residents and to conserve cultural heritage. However, this assessment does not deal with the issue of the balance between conservation and development aims. The Mayor certainly will have achieved the development aims of integration and modernization by applying the generic 'comprehensive redevelopment model'. The modified redevelopment model which phases clearance and re-building to facilitate local re-housing, now used in England and elsewhere, was never considered, as the latent aim of the project was to change both the physical and social structure of Sulukule. The potential impact of applying the generic 'neighborhood rehabilitation and community development model' was raised through the embryonic community planning processes, but was not seriously considered. The basic decision in all neighborhood regeneration programs - the balance between clearance and rehabilitation was taken behind closed doors, with no community involvement. The Mayor considered this decision irreversible, hence there were only minimalist responses to sustained criticism from UNESCO and the Sulukule Platform. The resulting modern housing development will be regarded very positively by the new owners of Sulukule but will remain condemned by some as the antithesis of conservation and interpreted by others as the harbinger of 'the Ottoman Historic Peninsula'.

Only a very few listed buildings are left in the area, some repaired, others waiting for repair. The commitment to comprehensive redevelopment meant that tangible cultural heritage was not given 
a high priority as it was not possible to design around a significant number of isolated historical buildings. Hence attempts by the Sulukule Platform to increase the number of listed buildings had little success and some listed buildings were illegally demolished, despite objections from GIMMKudeb [62]. Similarly, the Renewal Board failed to assess the archaeological heritage of a site occupied at least since Byzantine times in advance of construction work which would destroy any remains forever.

For most people living in Sulukule in 2005 the impact has been negative. Some of the resident owners could afford to purchase the right to be re-housed in Sulukule when it is re-built - they will be 'returnees' - whilst others reluctantly took the compensation and moved to cheaper accommodation elsewhere, often to adjacent neighborhoods. The tenants had no property rights. Many were evicted and re-housed themselves, initially with friends and family within the shrinking neighborhood housing stock, and eventually elsewhere. However, tenants were eventually offered flats in Tasoluk but few moved there and most of those who did soon left. The long distance re-location away from informal employment opportunities and the fragmentation of community mutual support systems meant that many could not keep up with the mortgage payments, so they sold and moved on, many returning to cheap rented property in old central neighborhoods [63]. It is not clear who will be living in Sulukule in two or three year's time. The 'returnees' will be one group. But the newcomers will mainly be those people to whom Sulukule owners sold, or the 'third party people' to whom the municipality sold properties it bought, either by negotiation or by expropriation from Sulukule owners. But the impact of increasing speculative sales of property rights means that some of the people who will first occupy the new Sulukule houses have not yet purchased them [64]. However, it is clear that Sulukule will have been transformed from a poor, diverse community to a prosperous and predominantly conservative middle-class neighborhood.

This outcome means that the Mayor used the powers of Law 5366 to implement the 'top-down' planned gentrification of Sulukule. He developed and implemented a neighborhood regeneration project which would have the inevitable impact of displacing many relatively poor homeowners and tenants. This raises the question of how the Mayor could repeat the claim, in the face of a continuous barrage of criticism, that this was 'the most social project in Istanbul', when it was clear from the outset that the intention was to radically change both the physical fabric and the social structure of the neighborhood. A partial explanation may be the Municipality's rudimentary understanding of the social structure, property ownership rights, and community life in Sulukule. The claim of a social project may have rested on two key, but ultimately false, assumptions. The first was that despite the house prices generated by low density and high housing, a higher proportion than was the case of homeowners would be able to return to the redeveloped neighborhood to enjoy a much improved quality of life. The second was that the relocation to a better quality neighborhood Tasoluk would also mean a better standard of living, and be socially and economically feasible for most of Sulukule's 2005 low income owners and tenants, irrespective of its location.

The financial and human resources to develop a 'bottom-up' application of the 'neighborhood rehabilitation model' were not available and the model cannot be developed by volunteers alone. But the informal planning processes in Sulukule demonstrated the possibilities for the application of this model in Istanbul. This would however mean the development of partnership working between the authorities and civil society organizations which has to emerge. However, the prospects of such a development will have been significantly enhanced, if the Sulukule cause celebre, like the Covent Garden cause celebre serves to inspire a generation of planners and architects to commit to community-based sustainable neighborhood regeneration. 
5.2 Impact on the prospects for the sustainable regeneration of the historic central neighborhoods and the deteriorating earthquake threatened 20th century neighborhoods

The Sulukule experience brings into sharp focus the question of 'whose Historic Peninsula'. If planned gentrification continues to exacerbate (real estate market-driven gentrification) the city's historic neighborhoods will be substantially gentrified within 15-20 years. This could well be the outcome of the ongoing implementation of the Fatih Renewal Areas Program. The Sulukule project was unique, in that none of the other Renewal Areas envisage comprehensive redevelopment. Both the Mayor and the Director of TOKI have publically acknowledged that mistakes were made in Sulukule, but without being specific about what the mistakes were [65]. But the Mayor is pressing ahead with the implementation of the Historic Peninsula Renewal Areas Program. The Fener-Balat Renewal Area may well add a process of planned gentrification to the unplanned gentrification initiated by the EU-UNESCO funded project 2000-2007 [43]. In the terms of this analysis the EU project attempted to apply the generic 'neighborhood regeneration and community development model' and develop a replicable process which would be rolled out across the Historic Peninsula and beyond. It was judged by UNESCO to have been successful, but apparently on the narrow basis that it had successfully restored 173 buildings and provided a range of community facilities, through a $7 \mathrm{~m}$ Euros investment, in an innovatory participatory process. But it failed in its principle objective of creating a replicable model because no system of means-tested grants and below-market rate loans was created to follow on from the EU subsidized investment which enabled poor families to stay in improved flats. The need for these new tools was emphasized well before the end of the project [29] and without them the partial implementation of the 'neighborhood rehabilitation and community development model' has triggered unplanned gentrification. In this context the Mayor has privatized the ongoing rehabilitation of the area by contracting a major construction company GAP Ltd. to develop a private sector-led rehabilitation model. But the lesson from the experience of Europe and the USA is that without the tools of grants and loans, the impact of the Fener-Balat Renewal Area will be to add planned gentrification to the unplanned gentrification and create an irreversible upward spiral of gentrification.

The Mayor of Beyoglu is responsible for the part of the World Heritage Site on the other side of the Golden Horn and prompted by the new legislation has also developed a program of Renewal Areas. It can be argued that some lessons have been learnt from the Sulukule. The first Renewal Area is in Tarlabasi, arguably the poorest, most socially diverse, and most run-down neighborhood in the municipality, but one where the development potential is greatest because it is adjacent to the business and tourism central area of Taksim. The Mayor also contracted GAP Ltd., but with a brief to develop and implement a more sophisticated and private-sector-led redevelopment process. Hence, from the outset this project employed community planners to work from an office within the area, co-operating with local people to identify their re-housing needs [66]. But the property transfer process has recently reached the demolition stage and there is increasingly intense controversy, comparable to the Sulukule experience, but without the international dimension that was generated by the human rights focused Roma support networks. Tenants are apparently being evicted and many families are reluctant to move to TOKI accommodation $40 \mathrm{~km}$ away. Thus, whilst the local planning process has been more sophisticated, the re-housing process has suffered from the same critical weakness - the absence of subsidized social rented housing to accommodate tenants in locations where they can survive economically and socially. The experiences of both Sulukule and Tarlabasi emphasize the need for an effective response to the OECD recommendation that

'...The city of Istanbul should urgently set up mechanisms to avoid increased gentrification and social exclusion from real estate market operations' ([4], p. 173). 
On a wider front, the redevelopment of Sulukule has become the cause celebre in a hitherto increasingly polarized debate about the purpose, scope and outcomes of urban and neighborhood regeneration. The resistance in Sulukule fuelled opposition to regeneration in other Istanbul municipalities where the market conditions for gentrification are by no means as favorable in the central historic neighborhoods. This is encapsulated in the slogan 'no Sulukule here', which is used by both some mainstream opposition (CHP -Republican Party) politicians and by neighborhood activists who have no trust in mainstream parties or municipal bureaucracies. This wider debate can be characterized in terms of a spectrum of views, each embodying a different view of the role of the state in urban development and regeneration. At one end of the spectrum there are those who argue that regeneration should simply be stopped. In this view urban regeneration has no legitimacy, at least under present economic and political conditions [67]. In the case of strategic urban regeneration projects it is a state assisted but market-dominated process that enables private interests to make major profits from office and hotel developments and from providing housing for the expanding elite classes created by globalization. None of the value created by redeveloping high demand strategic locations will benefit the poor in adjacent or nearby neighborhoods who may well be displaced. Hence the widespread opposition to the proposals debated in recent years for locations such as Galata Port and Haydarpasa (derided as Manhattan on the Bosphorus) and the controversy surrounding the Zaha Hadid urban regeneration project in Kartal [68]. Similarly, the same interests are served by planned gentrification - it is the poor who pay the price of regeneration in the central high demand neighborhoods. From this perspective these outcomes are the inevitable consequence of the logic of capitalism being expressed in the urban transformation processes generated by globalization, in a maturing democracy where a religious conservative ruling party has neither the motivation nor the capacity to move in another direction.

At the other end of the spectrum is a view that private sector-led urban regeneration should be enabled by the state so that Istanbul can compete effectively and realize its world city potential. This means major investment to provide the modern built environment needed by the expanding service industries, such as business and financial services, information technology and tourism, on which the future prosperity of the city will depend. The application of the generic 'property-led regeneration model' through large-scale urban regeneration projects is both essential and desirable. Whilst this may result in disruption and displacement, this is the price that has to be paid for the city to move forward. In the same vein, planned gentrification, which creates the conditions for more widespread spontaneous gentrification, is the only way to arrest the long run decline of the city's historic neighborhoods. In this view gentrification is not a problem - it is a major part of the solution. Overall, the role of government is simply to create the conditions which will enable the private sector to implement strategic urban regeneration projects and reverse the decay of the historic neighborhoods through profitable neighborhood regeneration programs. There is no alternative.

In this polarized debate the horrific predicted impact of the inevitable next earthquake has become 'the elephant in the room'. The gentrification controversy has overshadowed the issue of the need to develop implementable regeneration models replicable for the hundreds of deprived, neighborhoods where the threat is not from gentrification but from the next earthquake. This earthquake mitigation focused regeneration has not yet got beyond the urban design 'behind closed doors' stage, except in Kucukcekmece. Many local government officials and some academics blame the government's failure to pass the 2005 draft Urban Regeneration Law [69]. But amendments to existing legislation in mid 2010 will give the metropolitan authorities powers analogous to those provided by Conservation Law 5366.

The lesson of the impact of the Sulukule experience, in the context of the emergence of regeneration as a key urban policy issue in the past decade, is that there is now both a pressing need and an 
opportunity to move beyond this polarized debate to develop a practical alternative - the Istanbul application of the generic model of sustainable urban and neighborhood regeneration. This view is supported by the fact that the OECD has recently lent its weight to the need to address the key strategic issue of cross-subsidizing the regeneration of poor neighborhoods from a share of the value created by prestige projects:

'To combat the increasing threat of gentrification and social exclusion through the real estate market, the city of Istanbul should increase its managerial and institutional capacity to capture more of the real estate property value increases resulting from public investments in infrastructure and zoning changes' ([4], p. 174).

Significant progress has been made in preparing strategic development frameworks and local action plans for strategic urban projects and neighborhood regeneration. But with the exception of Sulukule there has been very little implementation at neighborhood level. Meeting the challenge of fully developing and applying the Istanbul version of sustainable urban and neighborhood regeneration requires integrated action at several levels in relation to both gentrification threatened neighborhoods and earthquake-threatened neighborhoods. At national level, revised legislation and policies are needed to establish a social rented housing sector that would provide affordable re-housing for tenants displaced by regeneration, to provide grants and /or below market rate loans to enable low income owners to upgrade their properties, to target public sector resources to earthquake threatened and deprived urban areas, and to regulate the market in order to capture market value uplift in ways that provide resources for neighborhood regeneration which would minimise gentrification.

At city level the authorities need to develop regeneration models for central neighborhoods which mitigate gentrification. In parallel the city should develop models for key strategic projects which integrate them spatially and financially with adjacent neighborhood programs. Priority neighborhoods in all twelve earthquake-threatened districts should be identified as the basis for a pilot program of both central area conservation-led and earthquake mitigation-led regeneration action. Participatory neighborhood action plans should field test new powers, procedures, and new financial and organizational models which are then up-scaled to meet both the earthquake threat and the threat of gentrification. This process will need a major capacity building program to create a cadre of professionals with the community development skills needed for sustainable neighborhood regeneration at all levels and regeneration policies and action programs will have to be developed in ways in which they contribute to the post-Copenhagen carbon reduction targets - the 'greening' of urban regeneration. This action agenda has recently been significantly endorsed by the National Urban Commission [70]. This was a significant milestone, but it will require political will at all levels of government to make the next decade as productive in implementation terms as the last one was in terms of innovation in planning.

The profitable implementation of strategic urban regeneration projects and gentrification of historic neighborhoods are both consistent with the logic of capital in an era of globalization. But it is not inevitable that urban and neighborhood regeneration will be dominated by socially regressive outcomes, unless it is held that the state acts solely in the interests of capital. The history of western democracies shows that to varying degrees social reform policies have mitigated many of the worst effects of capitalist urbanization. In the context of ongoing EU harmonization processes and Turkey's continued rapid economic development as the world's $17^{\text {th }}$ largest economy, it is well within the bounds of possibility that during the next decade Istanbul will build on its experience since the early 2000s to fully create and apply its version of the generic model of sustainable urban and neighborhood regeneration. 


\section{REFERENCES}

[1] Carmon, N., Neighbourhood regeneration: the state of the art. Journal of Planning Education and Research, 17, pp. 131-144, 1997. doi:http://dx.doi.org/10.1177/0739456X9701700204

[2] Gibson, M., Kocabas, A. \& Oztas, T., Sustainable Urban Regeneration in Istanbul as part of EU Harmonisation Process and Earthquake Resistant Housing Development - A Strategy and Action Plan, GIMM-MSU-LSBU, 59-Y and KDM 460.101, Istanbul, 2003.

[3] Goksin, A., Surdurulebilir Mahalle Yenileşmesinde Toplum Tabanlı Model: Kadıkoy - Fikirtepe icin bir Model Onerisi, unpublished PhD, MSGSU, Istanbul, 2008.

[4] OECD / DAC, Review of the DAC Principles for Evaluation of Development Assistance, 1998.

[5] Gibson, M. \& Kocabas, A., Turkish planning at a cross roads: false dawn or vision of new era? edn. A. Mengi, Kent ve Planlama: Gecmisi Korumak Gelecegi Tasarlamak, Rusen Keles'e Armagan Dizisi, II, pp. 165-201, Imge kitabevi: Ankara, 2007.

[6] Wilson, J.Q. (ed.), Urban Renewal: the Record and the Controversy, MIT Press: Cambridge Mass, 1966.

[7] Gibson, M. \& Langstaff, M., An Introduction to Urban Renewal, Hutchinson: London, 1982.

[8] Oxley, M. et al. Financing Home Owners' Repairs: Learning From Europe, York publishing services: York, 1999 in [2].

[9] Williams, P., Gentrification in Islington. Transactions of the Institute of British Geographers, New Series, 3, 1978.

[10] Blair, T.L., Rehabilitation: the social aspects. Official Architecture and Planning, 33(2), pp.126-130, 1970.

[11] Kocabas, A., Urban conservation planning in London and Istanbul: an international comparative study of two controversial decades - 1969-1989, LAP, Blackwell, 2010.

[12] Healey, P.S. et al., Rebuilding the City: Property-led Urban Regeneration, E. and FN Spon: London, 1993.

[13] Hamnett, C., Unequal City: London in the Global Arena, Routledge: Abingdon, 2003.

[14] Fainstein, S., Economics, politics and development policy: the convergence of New York and London. International Journal of Urban and Regional Research, 14(4), pp. 553-75, 1990. doi:http://dx.doi.org/10.1111/j.1468-2427.1990.tb00157.x

[15] Loftman, P. \& Nevin, B., Prestige projects and urban regeneration in the 1980s and 1990s: a review of benefits and limitations. Planning Practice and Research, 10(3/4), pp. 299-313, 1995.

[16] Parkinson, M., Combating Social Exclusion: Lessons from Area-based Programmes in Europe, Policy Press: Bristol, 1998.

[17] EC, Sustainable Urban Development in the European Union: A Framework for Action, COM/98/605 F, 1998.

[18] Leather, P. \& Mackintosh, S., Housing renewal in an era of mass home ownership. Implementing Housing Policy, eds P. Malpass \& R. Means, Open University Press, 1993.

[19] Leather, P. \& Mackintosh, S., Towards sustainable policies for housing renewal in the private sector. Directions in Housing Policy: Towards sustainable housing policies for the UK, ed. P.Williams, Paul Chapman Publishing, 1997.

[20] Gibson, M., The greening of housing policy. Housing and the Environment: A New Agenda, Housing Policy and Practice Series, eds M. Bhatti, J. Brooke \& M. Gibson, Chartered Institute of Housing: Southampton, 1994.

[21] Couch, C. \& Denneman, A., Urban regeneration and sustainable development in Britain. Cities, 17(2), pp. 137-147, 2000. doi:http://dx.doi.org/10.1016/S0264-2751(00)00008-1

[22] Roberts, P. et al. (eds), Urban Regeneration Hand Book, Sage: London, 2000. 
[23] Holmes, C., Mixed Communities: Success and Sustainability, Joseph Rowntree Foundation: York, 2006.

[24] Simon, P., Gentrification of Old Neighbourhoods and Social Integration in Europe. Cities of Europe, ed. Y. Kazepov, Blackwell: Oxford, 2005.

[25] Mayor of London, The London Plan: Spatial Development Strategy for Greater London, GLA: London, p. xii, 2004.

[26] Mayor of London, The London Plan: Spatial Development Strategy for Greater London, Consolidated with Alterations since 2004, GLA: London, 2008.

[27] www.southwark.gov.uk

[28] Kocabas, A., Urban Conservation Planning and Development Outcomes in Conservation Areas in Central Istanbul and in Central London: 1969-1989, published PhD, LSBU: London, 2000.

[29] Kocabas, A., Kentsel Donusum (/Yeniles(Tir)Me): Ingiltere Deneyimi ve Turkiye'deki Beklentiler, Istanbul: Literatur yayinevi, p. 10, 2006.

[30] Bayindirlik ve Iskan Bakanligi (BIB), Kentlesme Surasi: Komisyon Raporlari, cilt I, BIB: Ankara, 2009.

[31] Istanbul Metopolitan Planning Centre (IMP) Kartal Sub-centre, Kartal-Pendik Seafront Urban Transformation Project Competition Brief, 2006.

[32] Kocabas, A. \& Gibson, M., Handling earthquake threat. Planning Journal of the RTPI, 26 September, p. 16, UK, 2003.

[33] JICA \& GIMM, The Study on a Disaster Prevention / Earthquake Mitigation Basic Plan in Istanbul, GIMM: Istanbul, 2002.

[34] Ozaydin, G. \& Kocabas, A., Urban design as a necessary tool for developing projects in keeping with the traditional context: assessment of urban projects in Istanbul. Euro-Mediterranean Regional Conference: Traditional Mediterranean Architecture: Present and Future, Barcelona, July 12-15, 2007.

[35] Görgülü, T. \& Kaymaz, S., Türkiye'de barınma biçimlerinde yaşanan değişimler: son dönemde yapılan tüketim odaklı konutlar. Mimarlık, no. 337, 2007.

[36] ODTU, ITU, BU, YTU and IBB, Istanbul Deprem Master Planı, IBB: Istanbul, 2003.

[37] Kocabas, A., Neighbourhood Regeneration: English Practice and Turkish Prospects, LSBU: London, 2005.

[38] ITU, MSGSU, ODTU, YTU, Istanbul'un eylem planlamasına yonelik mekansal gelisme stratejileri arastirma ve model gelistirme calismasi sonuc bildirgesi. www.planlama.org, 01.06.2008.

[39] Gibson et al., Zeytinburnu Outline Strategy and Action Plan Framework: Building a Future in Europe, IBB-Tribal Consulting, 59Y and KDM 460.106, IBB: Istanbul, 2005.

[40] Diren, M., Master planning of Istanbul: legacy, current situation and future prospects. TKHV: Istanbul, 2010.

[41] Turgut, S. \& Ceylan, E., Bir Yerel Yonetim Deneyiminin Ardından: Kucukcekmece, AyazmaTepeüstü Kentsel Dönüşüm Projesi, Alfa: Istanbul, 2010.

[42] Kocabas, A., Urban conservation in Istanbul: evaluation and re-conceptualisation. Habitat International, a Journal of the Study of Human Settlements, Elsevier, p. 120, 2006.

[43] Ercan, M.A., How to shape up conservation-led regeneration initiatives regarding community needs. Middle East Technical University Journal of the Faculty of Architecture, 27(1), pp. 201-221, 2010.

[44] IMP, Istanbul Tarihi Yarımada Yonetim Planı Analitik Etüd Ara Raporu, Istanbul, 2010.

[45] Somersan, S. and Kirca-Schroeder, S., Resisting eviction: Sulukule Roma in search of right to space and place. Anthropology of Eastern Europe Review, 25(2), pp. 96-107, 2008. 
[46] Cetingoz, M., Neslisah ve Hatice Sultan Mahalleleri (Sulukule) kentsel yenileme projesinin surdurulebilirlik ve katılım baglamında incelenmesi, unpublished dissertation, MSGSU: Istanbul, 2008.

[47] www.trekearth.com, 17. 03.2008.

[48] Foggo, H., The Sulukule affair: Roma against expropriation. Roma Rights Quarterly, No.4, 2007.

[49] Istanbul - Fatih İlcesi 1. Grup 2 no.lu Yenileme Alanları Proje ve Uygulamalarına Ilişkin Protokol, 13.07.2006.

[50] www.radikal.com.tr, 18.03.2009.

[51] Sulukule Platform, Report on the Impact of Sulukule Urban Renewal Project, 25.04.2009.

[52] www.habervesaire.com/haber/1875/, 13.06.10.

[53] Accessible Life Association, The Sulukule Roma Neighbourhood Development Project, Application to the EC Delegation to Turkey, Strengthening Civil Society in the pre-accession process: NGO grant facility, 13.10.2006.

[54] UCL - DPU, Placing Sulukule: towards an alternative proposal to conserve the living heritage of Romans, www.ucl.ac.uk, 2008.

[55] www.febayder.com/content/fatih-belediyesi-ne-yapmaya-calisiyor, 25.4.2010.

[56] www.artizinconnu.com/Belgesel.

[57] Yeni Mimar, 'Kent yonetiminde yeni bir asamaya geciliyor', 18.05.2007.

[58] www.mimdap.org, 'Avrupa Birligi Sulukule'de', 26.06.2007.

[59] Foggo, H., 'Sulukule'de alternative plan calismasi basladi', BIA Haber Merkezi, 25.06.2007.

[60] www.arkitera.com, 'Meclis Sulukule dosyasini kapatti, 18.01.2008.

[61] UNESCO - WHC, Historic areas of Istanbul. Thiry-third Session: Seville, Spain, 22-30.06.2009.

[62] www.gencmimar.com, Kentin tozu. 03.06.2009.

[63] www.cnnturk.com, Sulukule nereye gitti. 13.01.2010.

[64] www.hurriyetdailynews.com, Istanbul land to sell for five times amount Roma given. 22.09.2010.

[65] www.radikal.com.tr, 20.10.2009.

[66] Goksu, F., Tarlabasi, Stratejik Sosyal Plan (2008-2010), unpublished report, 2009.

[67] Bozkulak, S., Sermaye, kentsel dönüşüm ve varoş: fakirin malı, zenginin hazinesi. Birgün, 14.05. 2010.

[68] Kocabas, A., Regeneration of Kartal: challanges, opportunities and prospects for the future. The sustainable City VI: Urban Regeneration and Sustainability, eds C.A. Brebbia, S. Hernandez \& E. Tiezzi, WIT press: UK, 2010.

[69] Altun, L., Kentsel Dönüşüm. TMB Gündem, 01, pp. 44-77, 2009.

[70] T.C. Bayindirlik ve Iskan Bakanligi, Kentlesme Surasi Komisyon Raporlari, www.bayindirlik. gov.tr,. 2009. 